\title{
A MULTIPARADIGM APPROACH TO INTERPRETATION IN ARCHITECTURE: EXPLORING IDEOLOGICAL MEANING IN POLITICAL PARTY HEADQUARTERS Aslı ÇEKMİ̧̧*, Orhan HACIHASANOĞLU**
}

Received: 26.09.2011; Final Text: 20.10.2014

Keywords: Architecture; meaning; literary criticism; political party headquarters; ideology.

\footnotetext{
* Department of Architecture, İstanbul Technical University, İstanbul,TURKEY.

** Department of Architecture, Özyeğin University, İstanbul, TURKEY.
}

\section{INTRODUCTION}

The attempts to make sense of the built environment are conceptualised within various disciplines also including linguistics and literature. Current theories in literary criticism support different movements in meaning studies. This paper proposes a multiparadigm approach for interpreting and knowing in architecture by employing disparate theoretical perspectives of literary criticism. The research intends to encompass intentionalist, structuralist and post-structuralist paradigms, where the textual meaning is questioned on the basis of the author, the text itself and the reader respectively. The first part elaborates on these major paradigms of literature and then provides extensive review in architectural studies.

The multiparadigm approach was specifically applied in this paper to political ideology (as the meaning) and party headquarters (as the text) through a detailed case study. Headquarters have always had a political identity associated with party ideology, which is more prominent than its function as the main office. As an early example, 'Palazzo Littorio,' the new headquarters of the National Fascist Party of the Mussolini period in the 1930s, reflected the idea of the totalitarian regime and radical nationalism in terms of urban design, spatial features, architectural programme and even the building material used (Marcello, 2007). Oscar Niemeyer designed for the Communist Party in Paris in the 1970s. The Marxist architect deemed his building as "the house of the worker" and "a sign of the socialist society," which had a sinuous sculptural shape presenting a dramatic contrast to the centuries-old palaces and to the axial formality of the cityscape (Wise, 2010). Recently built headquarters in Berlin for SPD in 1996 and for CDU in 2000 also have strong links to the identity and ideology of the parties.

The case study here investigated four main political parties and their headquarters in Ankara, the capital city of Turkey. The relation between the buildings and ideologies of the parties has been recently studied, which 
represents conceptual readings by researchers (Gürallar and Boyacıoğlu, 2008; Demirkol, 2008; Yılmaz, 2009). However, this paper discusses the relation through a multi-faceted reading based on author, text and reader. Accordingly, ideology embedded in headquarters was illustrated as a reality formed by the architect or people from a singularist to multiplist position in meaning creation, or within the linguistic structure of the building. The results showed different forms of ideological meaning at each level, which are parallel with the theoretical grounds of the methods used.

Even though this research is limited to ideology and party headquarters through a single case study, it aims to draw a wide theoretical framework and multi valued logic of inquiry for meaning studies in architecture, thereby increasing awareness of the importance of methodology in architectural interpretation.

\section{MULTIPARADIGM APPROACH}

For a multiparadigm approach, intentionalism, structuralism and poststructuralist reader-response criticism are adopted from the literary theory in order to reveal the meaning in an architectural work.

In early tradition, literary theory supports the idea that an author's intent is essential to a proper understanding. Intentionalism, having roots in romanticism, puts forth that the work of art possesses a meaning that the artist himself only truly knows. The work of art becomes a bridge to the mind of the artist; thereby finding out what it means requires finding out what the creator meant originally (Dutton, 1987). According to Hirsch $(1967,1976)$, who is the pioneer theorist of intentionalism, there might be many interpretations of a text, but the construction of textual meaning depends on the objective interpretation of the author; which is the permanent and determinate meaning. Without the notion of authorial intent as a guide; and having a standard of interpretive correctness, the criticism will take on a cognitive status due to the various subjective and competing interpretations of the work (of literature or of art). Although the fundamental role of the author is still defended (including recently Knapp and Michaels, 1992; Irwin, 1999; Carroll, 2001), to judge a work by assuming the intent or purpose of the author is described as an "intentional fallacy" (Wimsatt and Beardsley, 1954). Actual intentionalism is rejected since being a tradition that inappropriately seeks evidence of the work's meaning outside the work itself (Irvin, 2006). This builds the road for formalist movement; new criticism and the broad impact of structuralism.

Structuralist linguistics is not concerned with the particular and unique thoughts of the author in the creation of the text, nor how it appears to the reader, rather it describes a language system both author and reader comply with to make meaningful communication possible. Saussure (1986), the founder of semiology, defines 'sign' as the relationship established between the signifier and the signified, and also draws its horizontal and vertical axes as syntagms and paradigms. A sign may refer to other concepts, besides denoting its real object (literal meaning), which are called as connotations (Barthes, 1999). Fiske (1990) demonstrates metaphor and metonymy as the methods of creating intentional meanings. Peirce (19311958) draws attention to "semiosis" as the sign creation and interpretation processes and cites the trilogy of icon, index and symbol which would emerge from the interrelation between the sign and its object. Built upon Peirce's semiotic diagram, Morris (1955) defines three levels of interrelation 
pertaining to a sign; syntactics (the form), semantics (the meaning), and pragmatics (the use). Showing a shift towards the post-structuralist criticism, "social semiotics" (Hodge and Kress, 1988) accepts the power of text in society, and tries to explain meaning-making in a human signifying practice shaped by political interests and ideologies in order to influence individuals and societies. Barthes (2001) postulates that the contextual level of connotation produces and keeps alive the effective ideology of the general public in cultural and political terms.

The last tradition is the reader-response criticism (particularly "reception theory") which appreciates readers of the text as the creator of the meaning through individual consciousness prior understandings. Porter (2011) stresses that the classical past exists only if the "illusion" that the classical studies and their objects are timeless and eternal is received. Reception theory brings a paradigm shift in literary studies by giving attention to the reader's role in literature (Eagleton, 2008), different from Romanticism; a preoccupation with the author, and New Criticism (Formalism or Structuralism); an exclusive concern with the text. The notion of reception is grounded in phenomenology and hermeneutics. The subjective perception and consciousness of the reality gained by experiences, which phenomenology studies deal with, put emphasis on the readers' involvement in meaning production. Iser (1988) states that the text only takes life when it is realized and this realization cannot be independent of the individual disposition of the reader. Reception theory also has hermeneutical insights advocating the inquiry of interpretive narration derived from conventions and personal opinions. Jauss (1982) writes that "a literary work is not an object that stands by itself and offers the same view to each reader in each period". Also, he assumes that the aesthetic value of a work can be determined by the influence or effect on its audience, referring to the relationship between the texts and "horizons of expectation". He stresses that the reader approaches a text armed with the knowledge and experience gained from interactions with other texts.

From an architectural perspective, the intentionalist account overplays the creator identity of the architect in the design process, thereby trying to understand the meaning of the work through the lens of the architect by asking what he or she actually meant. Proctor (2006) highlights that to query meaning from interviews and autobiographies, where architects draw a guideline to the reader for interpretation, is inherently privileging an authorial concept of the architect's role. Architectural historians unlike critics are interested in an architect's intention since they feel the need to abide by telling the truth. However, the intentions cannot completely determine what constitutes an architectural work as a single accurate interpretation (Goodman, 1988). One reason depends on the nature of practice in that the architectural work is collaborative (Proctor, 2006), as well as it being subject to manipulation by other actors such as power holders. Also, the result of a work of architecture may change in the course of time, as The Leaning Tower of Pisa is not intended to have a four-degree slant from the vertical (Fox, 2009). The work of architecture means different things to different groups at different times, which supports the reception based interpretation.

The structuralist approach and semiotics is very much appreciated to reach meaning in architecture with an attempt to create a 'design language,' and understand works within this language. Eco (2003) adopts an approach keeping the frame of the signifier and the signified, and postulates that 
an architectural object has a definite; particular signified which is "the potential of the function" of that object. The action attributed to the object refers to its denotation, whereas connotations give social, cultural and ideological clues about this action, such as the quality of occupation inside. Similarly Jencks (1980) defines the architectural sign as a twofold entity having the planes of expression (signifier) and concept (signified). The concept includes architectural ideas, aesthetic meanings, social and religious beliefs, ideologies, functions, way of life and so forth. Based upon the relations of icon, symbol and index, Norberg-Schulz (1965) and Preziosi (1979) interpret the semantic relations that pertain to an architectural sign. Also Jencks (1981) emphasizes metaphor in architecture through a physical analogy, as people look at buildings with the affinity they have for another object. In sum, structuralists assert that since language exists in objective patterns the works are common to all humans. So, it becomes possible to interpret buildings when we discover how its composition demonstrates the structural principles (Tyson, 2006), including the assumption of the creators' intentions and people's experiences that emerge in the same language system.

As the last approach, reader response theories encourage people (including everyone in a community) to go beyond the meaning dictated by the architect (and the building) to discover their own true meaning of the architectural work. The origin of reception in architecture comes from the movements in "art" that is "no longer lives in and for itself but for its connections to the outer world" (Kemp, 1998), which presents the space as a perceived, experienced and lived reality. In a similar way that the gaps and blanks in the text and the idea of its completeness in reception theory, inviting the reader to gain an active role in the production of meaning, a design has no real existence until it is lived. Siu (2003) states that a design is redefined by the users in ways that may be different from those of designers, planners, or policy makers. By taking the audience into account, the reception theory incorporates the aesthetics of daily life and the cultural views of a society in the architectural design through a participatory process (Robinson, 2004). Additionally, reception theory promotes a non-specialist evaluation of architectural work, which is conventionally addressed in its own discipline and practice.

\section{CASE STUDY}

\section{Ideologies and policies}

Established in 2001, AKP (The Justice and Development Party) came to power in the 2002 general election for the first time and still constitutes the majority in parliament as the current government. The Party puts forth a lifestyle which embraces the moral values of civil society and can be included in Islamic politics. Party policy is based on evolutionary and transformational principles and shies away from revolutionary visions (Ayhan, 2007). It has a culturally conservative, patriarchal, religious stance and its public image is one of a party that adheres to the past and traditions.

CHP (The Republican People's Party), the oldest political party in Turkey, was founded by Kemal Ataturk at the time of the Turkish War of Independence. CHP established a new government in 1923 and carried out many reforms. The party has a social democratic and revolutionary identity within the frame of Kemalist ideology. CHP is positioned on the left in the 
ideological spectrum, pursuing a policy which embraces and stands for concepts such as national unity, Turkish identity, secularity and social state of law (Önkaş, 2006).

Dating back to 1969, MHP's (The Nationalist Movement Party) main ideology can be expressed as "ülkücülük" (idealism), nationalism and an integration of Turkishness and Islam. Within its patriarchal structure, MHP stays on the right-wing nationalist end of the political spectrum (Çınar and Arikan, 2002). The party's nationalist principle means commitment to history, origins and traditions and is supported by powerful symbols such as the party's logo akin to the flag of the Ottoman Caliphate.

Founded in 1983, ANAP's (The Motherland Party) ideological approach, at that time, centred on a policy that combined nationalist, conservative, liberal and democratic tendencies under the name of political reconciliation. In its eight year ruling period it pursued a policy which strengthened the central authority and supported Turkish-Islamic synthesis (Belhan, 2005). The party gradually lost power after 1991 and was left outside the parliament in the 2002 election and in other successive elections.

\section{The Headquarters}

Opened in 2007, the AKP Headquarters (Figure 1), with the simplicity of its geometric form, is a solid prism of rectangles. The only mass movement is on the top floor which is designed for the sole use of the president. The building is symmetric in layout. It has a massive-appearing; a grandeur of scale with monumental gates, of which especially the protocol entrance is the focal point. In addition, there are some traditional architectural elements such as roof type and material, eaves, domes and octagonal star motif.

Inaugurated in 2006, the CHP Headquarters (Figure 2) has a dynamic expression in its fragmental composition. Offices are placed in a transparent mass rising on a cult base covered with a local material which is for public activities. The whole composite structure terminates with a bending roof slab. The interior design of the building is shaped around the atriums to create a visual integrity. The Central Executive Board (CEB) room in the form of an ellipse plan standing out on the building's mass is the focus of greatest emphasis within the design.

The MHP Headquarters (Figure 3), built in 2004, has an extraordinary design where various disparate masses are joining together. The office blocks define the main mass and the borders of an atrium. Two concrete shafts (the main circulation) rise from the void and a compressed concave cup (a cafeteria and heliport) sit on them. The building's entrance is reminiscent of Seljuk portals, where also the replicas of Orkhon script are placed. The party leader's section, which strongly refers to traditional architecture, is considered as a separate block. There is also a special venue for religious festival (bayram) greetings.

The ANAP headquarters (Figure 4) differs from the other three in terms of time, as it was built in 1989. The building is not as high as the others with a horizontally developed modest outlook in size. It was designed by articulating three masses of different size and heights on a linear schema (the auditorium, office block and entrance mass). The entrance hall was considered especially important in terms of visual, aesthetic and interior 
Figure 1. The AKP headquarters (Çekmiş, 2009).

Figure 2. The CHP headquarters (Çekmiş, 2009; Atabaş, 2006).

Figure 3. The MHP headquarters (Çekmiş, 2009).

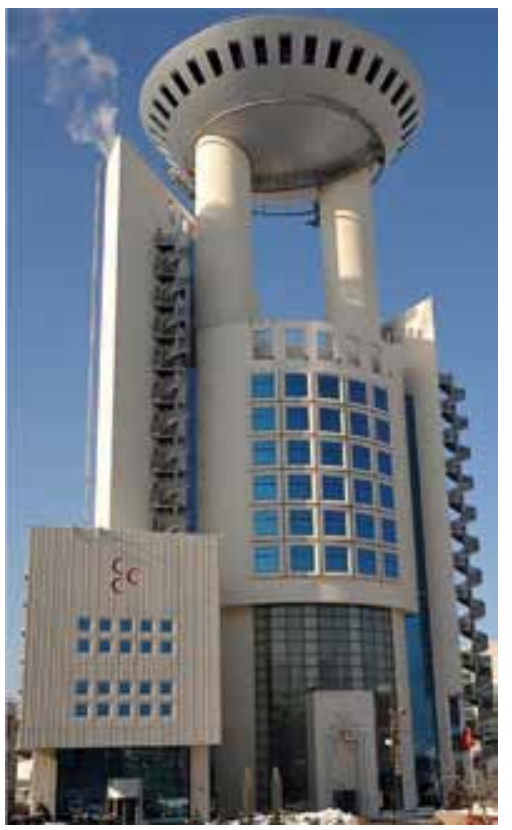

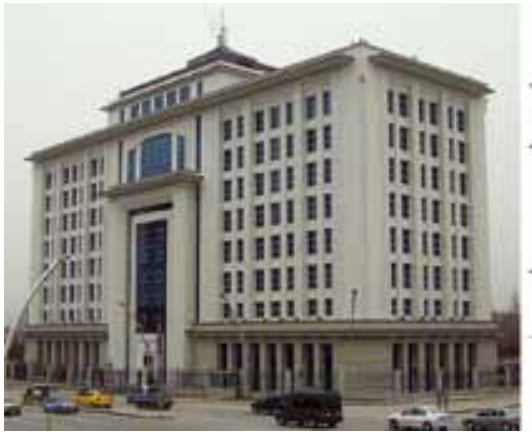
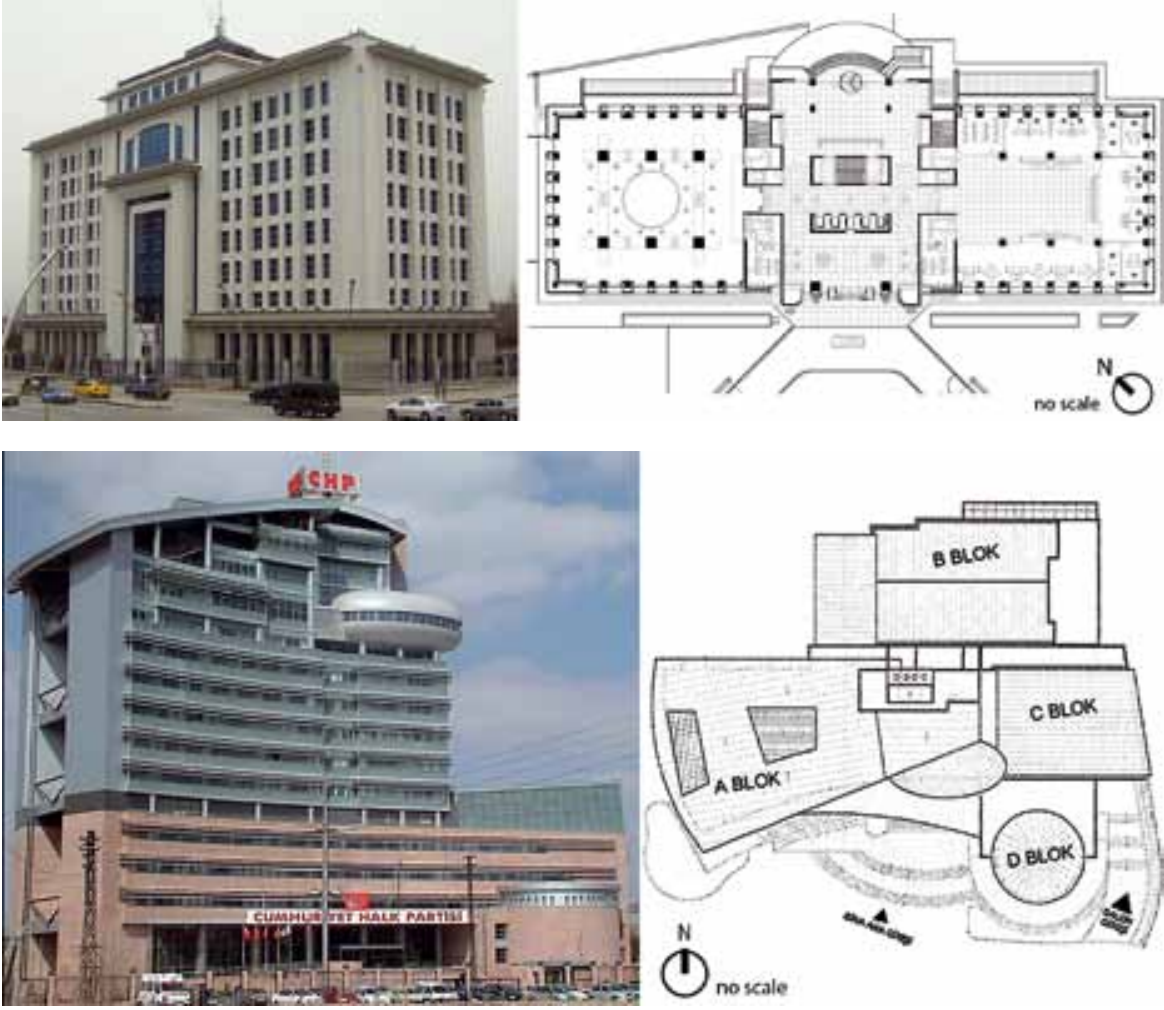

design. Additionally, the CEB room and the balcony of the leader's office protrude from the mass to take attention.

\section{Analysis}

A multiparadigmatic analysis was conducted by using three different ways of knowing and valuing an architectural work. Table 1 shows the outline of the research by signifying what we intended to find by using different paradigms, and to this end where we looked and by means of what.

Based on intentionalism we examined whether ideology was an important parameter when the meaning was produced by the architect. The design approaches of architects were posed during in-depth and semistructured interviews (Çekmiş, 2009). Following a structuralist tradition, we concentrated on the 'text' by asking how ideology is semantically embedded in architectural work. Through doing this the intention was to uncover the underlying system of language in the design of the headquarters. Based on the reception theory, we targeted the meaning by

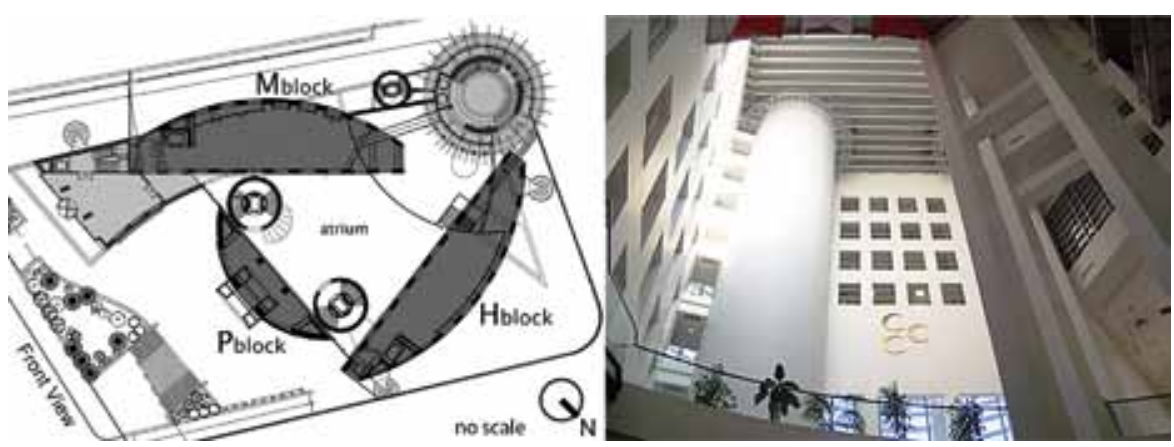


Figure 4. The ANAP headquarters (Çekmiş, 2009; Tekeli and Sisa, 1994).
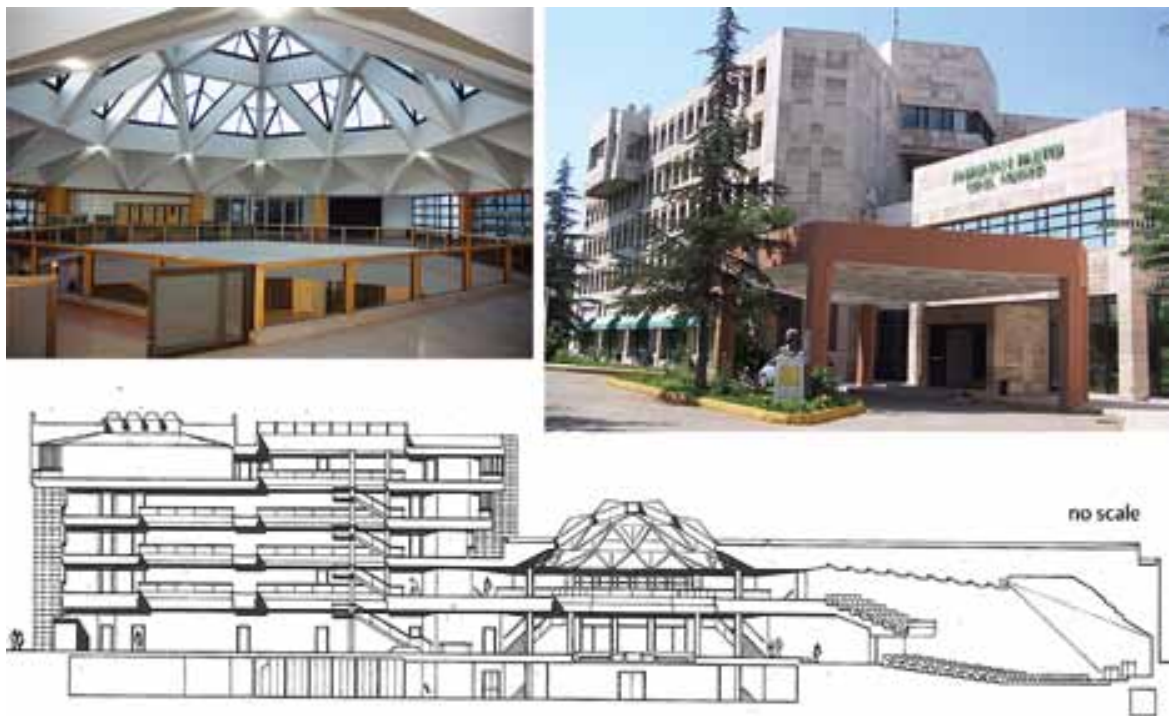

considering who would read the text. The buildings were open to public interpretation even those by users and visitors. Thus, we aimed at a mixed readers group gathered from various social and cultural backgrounds, also including party members who work in the headquarters. 210 people in total were selected from an average sample in terms of sex, age, education and occupation. Their subjective understanding and consciousness, which could be associated with party ideology, were obtained through openended questionnaires about the headquarters.

\begin{tabular}{|c|c|c|c|}
\hline Paradigms: & Intentionalism & Structuralism & $\begin{array}{l}\text { Post-structuralism } \\
\text { Reception Theory }\end{array}$ \\
\hline $\begin{array}{l}\text { Criterion of } \\
\text { textual } \\
\text { meaning: }\end{array}$ & $\begin{array}{l}\text { Author } \\
\text { Architect }\end{array}$ & $\begin{array}{c}\text { Text } \\
\text { Building }\end{array}$ & $\begin{array}{l}\text { Reader } \\
\text { Citizens }\end{array}$ \\
\hline $\begin{array}{l}\text { Characteristic } \\
\text { of meaning: }\end{array}$ & $\begin{array}{c}\text { One, the same, } \\
\text { permanent meaning }\end{array}$ & $\begin{array}{l}\text { Building's internal } \\
\text { evidence: the components } \\
\text { themselves and their } \\
\text { connoted meanings }\end{array}$ & $\begin{array}{c}\text { Many, different, } \\
\text { subjective meanings }\end{array}$ \\
\hline $\begin{array}{l}\text { The aim: } \\
\text { in terms of } \\
\text { ideological } \\
\text { meaning }\end{array}$ & $\begin{array}{c}\text { "artistic" } \\
\text { Context of the } \\
\text { building's genesis }\end{array}$ & $\begin{array}{c}\text { "objective" (thing-in-itself) } \\
\text { Intrinsic value of the } \\
\text { work - } \\
\text { Relationship between } \\
\text { building's ideas and its } \\
\text { form }\end{array}$ & $\begin{array}{l}\text { "aesthetic" } \\
\text { Cognitive, relative } \\
\text { and historical } \\
\text { evaluation }\end{array}$ \\
\hline $\begin{array}{l}\text { Research } \\
\text { subject: }\end{array}$ & $\begin{array}{l}\text { Design decisions, } \\
\text { intents and purposes } \\
\text { (before the } \\
\text { construction) }\end{array}$ & $\begin{array}{l}\text { Patterns exist within the } \\
\text { building; its structural } \\
\text { elements and materials }\end{array}$ & $\begin{array}{l}\text { Personal } \\
\text { interpretation; } \\
\text { opinions and } \\
\text { impressions }\end{array}$ \\
\hline $\begin{array}{l}\text { Research } \\
\text { instrument: }\end{array}$ & $\begin{array}{l}\text { Interviews } \\
\text { Also if available } \\
\text { other materials of } \\
\text { manifestos } \\
\text { such as diaries and } \\
\text { (auto)biographies }\end{array}$ & $\begin{array}{l}\text { Linguistic analysis of } \\
\text { buildings } \\
\text { by using semiotic } \\
\text { vocabulary; index, icon, } \\
\text { symbol, metaphor, } \\
\text { metonym, etc. }\end{array}$ & $\begin{array}{l}\text { Questionnaire } \\
\text { Enabling } \\
\text { active reading } \\
\text { (expectation and } \\
\text { participation) }\end{array}$ \\
\hline
\end{tabular}

Table 1. The multiparadigm approach in case study. 


\section{Results and Discussion}

From the intentionalist perspective, architects stated how party ideology and identity was involved in the design idea. In the AKP headquarters, the architect wanted to apply Ottoman and Seljuk architecture, also TurkishIslamic art by means of expressing historical continuity. The characteristic of neoclassical architecture was attributed to the strength of the state and ruling party. A centralist and hierarchic system was also emphasized in the project. In the $\mathrm{CHP}$ headquarters, almost all design decisions were derived from the principles of socialism (like equality and democracy through the emphasis on the CEB room). The elements of building composition were represented as the components of nation-state formation. For the architect, the revolutionary and reformist identity materialised as an "avant-garde" architectural design without any historical or traditional reference to conservative ideas. In the MHP headquarters, the architect placed $\mathrm{M}, \mathrm{H}$ and $\mathrm{P}$ office blocks in the form of a spring in a reference to the party's logo (a 3-crescent red flag). The unusual synthesis of traditional and futuristic styles was remarked as the result of the party principle which maintains their identity (history, culture and folklore) while integrating with the modern world. Respect and loyalty towards presidency also became an important design parameter. The architects of the ANAP building told that discarding the certain ideology of the party they aimed at a headquarters for a corporation acting as a candidate for the state governance, thereby reflecting a certain degree of solemnity and prestige. Besides the purpose of creating a rich interior space, the hexagonal plan of the entrance hall and its high dome made up of reinforced concrete and glass were reminiscent of the party's honeycomb logo. Additionally, the presidency and senior management were given importance in the mass design. Overall, this part of the analysis showed that the buildings were designed quite according to the principles and policies of the party as well as their identity elements. However, the conceptual links, and the way the ideology materialised was the architects own interpretation. The balance between assigned meaning and architectonic quality would also depend on the creator. For example, the arrangement of the MHP office blocks is not perceived as the architect intended. In addition, users are not happy with the enclosed atrium which is also a result of that stylistic pursuit within the layout design.

Following the structuralist notion, semiotic tools were used to reveal the underlying rules and conventions in the headquarters. The buildings as the main office of the party fulfilled the functional requirements of a certain architectural programme, which indicated denotation. However, we were interested in connotations as the headquarters expressed an implicit and secondary meaning which was associated with the party's identity and ideology. The connection between headquarters and ideology was expressed by index when the political idea was introduced by space, function and form; like apparently between the CHP building and party's social democratic identity. The similar architectural emphasis on the centralist corporate structure and presidency could also be regarded as an index. Symbolism was found in the AKP and MHP buildings, where the Ottoman, Seljuk, Turkish and Islamic elements stood for the conservative and traditionalist identity. Those architectural signs bore ideological clues about the values of its referent through an arbitrary and common acceptance. The ANAP and MHP headquarters had icons which represented a structural similarity relation that the architectural signs were in the resemblance of the party's visual identity elements. The AKP building has a noble and cordial expression as if a state building 


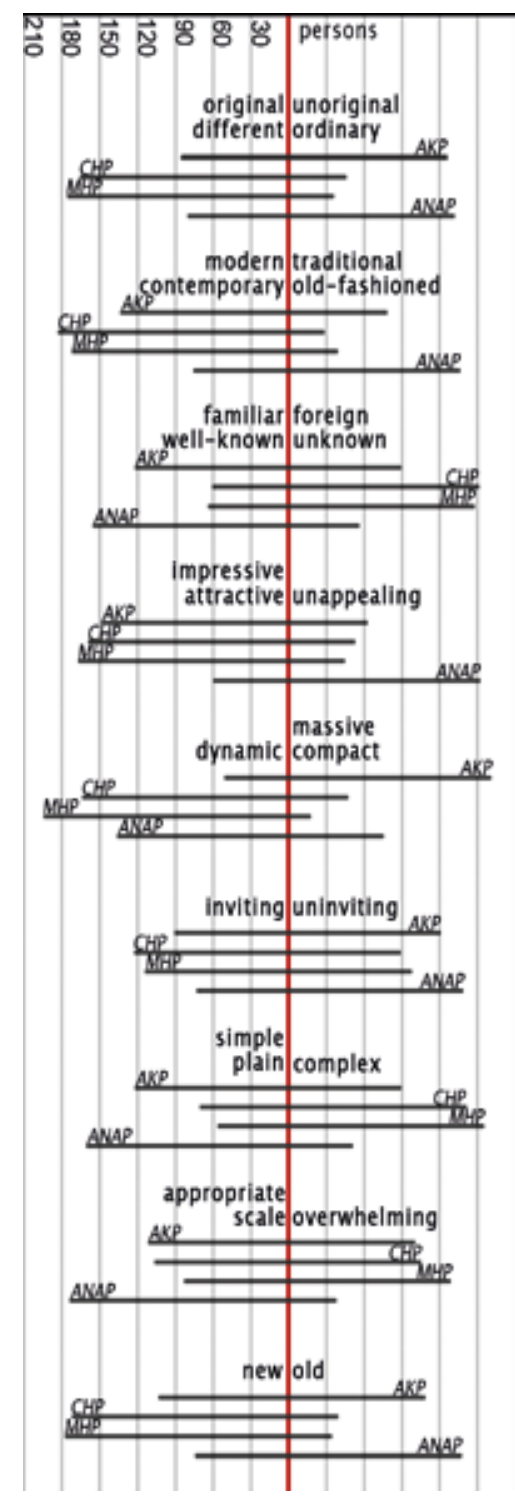

Figure 5. The diagram showing readers' responses. which defines metonym. Metaphors given for the CHP CEB room were; 'a soldier with a garrison cap,' 'a villager with a cap bent to one side' and 'an Amazon woman with one breast,' where soldier, villager and woman were important concepts in the policy of the party. In short, structuralist enquiry interpreted the buildings by using linguistic rules and deterministic schemes; by conceptually re-framing the intentions of creator and also proposing strict guidelines to follow while experiencing and understanding the buildings.

The analysis depending on reader response criticism considers readers' reactions as vital to interpreting the meaning of the headquarters. Thus, our concern became the beliefs taken towards the headquarters, also emotions evoked by them. The most cited adjectives by participants to identify each building in relation with the other 'texts' were represented in Figure 5. In many value groups the $\mathrm{CHP}$ and MHP buildings remained in one side such as original, unfamiliar and new whereas the AKP and ANAP buildings were at the other. Even though the AKP headquarters was also built recently, this result is possibly related to the compact and massive design of the building. In contrast, the $\mathrm{CHP}$ and MHP buildings were described as more dynamic and contemporary. The MHP headquarters was portrayed as the most complex and overwhelming building due to the gigantic dimensions of the architectural elements despite its fragmented composition. In textual context, the ANAP Headquarters differs from the others, since people are reading the architectural work more than twenty years after it was created. While it has more space in urban memory, it has also been subject to wear and tear in the course of time. This situation proves the argument of the reader response critics saying; the meaning of the text cannot be located in the past (neither in the mind of the creator nor in the constant presence of the work), but fully located within the reading community. Accordingly, while the simple and appropriate scale was an architectural and rather objective judgement, its being familiar, old-fashioned and old was mostly related with the current reading of the building. In addition, the age of the building, also the political predicament of the party may give rise to negative opinions like unappealing and uninviting. Overall, this paradigmatic approach allows us to reach historical, subjective, aesthetic and biased interpretations and the collective opinion of a certain cultural and social group. It is also a comparison of buildings through a parallel reading. People reading demonstrated a different response in terms of ideological meaning in buildings than the architects devised. The relation between ideology and headquarters is relatively weak, indirect and unobtrusive at this interpretation level. People seemed more interested in the architectural features of the buildings such as their scale and form, rather than abstract ideological connections. An ambiguous match can be cited between the notions: modern, original and foreign, and the ideological stance of $\mathrm{CHP}$ and MHP in part. The ideological links are occasionally conceptualized through the current political power of the party in a representative manner. For instance, the AKP headquarters were seen as impressive, plain and massive, where the strong and steady image of the ruler party can be accordant with the monumental and classical design of the building.

The resulting ideological interpretations of party headquarters match up with our aims by the three paradigms stated at the beginning; the artistic, objective and aesthetic productions of meaning. We can also further our understanding by deepening the case study analyses. Architects' other designs and if any of their other works for the party can be evaluated to see 
their styles and approach to architecture. The sign study in semiotics can be transformed into a communication process; the transmission of a message from a sender to a receiver, which is made up of encoding, medium of transmission, decoding and feedback. And also, the readers' profiles can be classified to investigate whether their answers correlate with their political advocacies or the demographic data of the survey. For example, people would probably reflect their affinity for and prejudice against parties when they review their headquarters.

\section{CONCLUSION}

This study examined ideology in the design of four headquarters in Ankara by utilizing three interpretation methods from literary studies; the author, text and reader oriented criticism. These techniques for reading texts supported different philosophical claims about meaning, which was produced by designer; was shaped in linguistic structures; and was a cultural construction of human subjects. Based on their point of view, each interpretation level established different aspects of ideological meaning of political headquarters.

The main contribution of this paper is presenting different perspectives to meaning studies in architecture, which could be applied to many research cases. Intentionalism is an appropriate method to probe unique creation processes of architectural products. The structuralist approach can be used when more objective conclusions or sets of design codes are needed. However, the reader-oriented theories in the post-structuralist tradition is more appreciated and accepted today than the other methods, since it opposes fixed, global and ahistorical readings.

\section{BIBLIOGRAPHY}

ATABAŞ, K. (2006) CHP Genel Merkezi Ankara, Arredamento Mimarlık (193) 78-86.

AYHAN, A. T. (2007) 2000'i Yıllara Doğru Türkiye'de Muhafazakar Siyaset "Ak Parti örneği", unpublished Master's Thesis, Kamu Yönetimi Bölümü, Gazi Üniversitesi, Ankara.

BARTHES, R. (1999) Elements of Semiology, Hill and Wang, New York.

BARTHES, R. (2001) Mythologies, Hill and Wang, New York.

BELHAN, Ş. (2005) Anavatan Partisi'nin Kuruluşu ve İktidara Gelişi, unpublished Master's Thesis, Kamu Yönetimi Bölümü, Dokuz Eylül Üniversitesi, İzmir.

CARROLL, N. (2001) Interpretation and Intention: The Debate between Hypothetical and Actual Intentionalism, Beyond Aesthetics: Philosophical Essays, Cambridge University Press, Cambridge; 197213.

ÇEKMIŞ, A. (2009) Siyasi Parti İdeolojilerinin Parti Genel Merkez Binalarına Yansıması, unpublished Master's Thesis, Mimarlık Bölümü, İstanbul Teknik Üniversitesi, İstanbul.

ÇINAR, A., ARIKAN, B. (2002) The Nationalist Action Party: Representing the State, the Nation or the Nationalists?, Political Parties in Turkey, eds. B. Rubin, M. Heper, Routledge, New York; 25-41. 
DEMIRKOL, H. G. (2008) Erk ve Mimarlık ilişkileri Açısından Parti Merkez Binalarl, Erk ve Mimarlik / Power and Architecture, XX. International Building and Life Congress Proceedings (20-22 March 2008) ed. M. Taş, UCTEA Chamber of Architects Bursa Section, Bursa; 112-6.

DUTTON, D. (1987) Why Intentionalism Won't Go Away, Literature and the Question of Philosophy, ed. A. J. Cascardi, Johns Hopkins University Press, Baltimore; 192-209.

EAGLETON, T. (2008) Phenomenology, Hermeneutics, Reception Theory, Literary Theory: An Introduction, University of Minnesota Press, Minneapolis; 47-78.

ECO, U. (2003) Functions and Sign: Semiotics of Architecture, Semiotics of Nonverbal and Complex Systems (vol.3), Semiotics, eds. M. Gottdiener, K. Boklund-Lagopoulou, A. Lagopoulos, SAGE, London; 241-91.

FISKE, J. (1990) Introduction to Communication Studies, Routledge, London.

FOX, R. N. (2009) Interpreting Architecture: A Krauszian Approach, unpublished Master's Thesis, California State University, Long Beach.

GOODMAN, N. (1988) How buildings mean, Reconceptions in Philosophy and Other Arts and Sciences, eds. N. Goodman, C. Z. Elgin, Hackett Publishing, Indianapolis; 31-48.

GÜRALLAR, N., BOYACIOĞLU, E. (2008) Üç Parti - Üç Bina: Farklı Siyasi Kimliklerin Başkent Ankara'da Temsili, Kim(lik)lerin Tasarımı, 4T Türkiye Tasarım Tarihi Topluluğu Seminer Bildirileri (12-13 May 2008) eds. T. Balcıoğlu, G. Baydar, İzmir Ekonomi Universitesi, İzmir; 85-96.

HIRSCH, E. D. (1967) Validity and interpretation, Yale University Press, New Haven.

HIRSCH, E. D. (1976) The Aims of Interpretation, University of Chicago Press, Chicago.

HODGE, R., KRESS, G. (1988) Social Semiotics, Polity Press, Cambridge.

IRVIN, S. (2006) Authors, Intentions and Literary Meaning, Philosophy Compass 1(2) 114-28.

IRWIN, W. (1999) Intentionalist Interpretation: A Philosophical Explanation and Defense, Greenwood Press, Westport.

ISER, W. (1988) The Reading Process: A Phenomenological Approach, Modern Criticism and Theory: A Reader, ed. D. Lodge, Longman, New York; 211-28.

JAUSS, H. R. (1982) Literary History as a Challenge to Literary Theory, Toward an Aesthetic of Reception, University of Minnesota Press, Minneapolis; 3-45.

JENCKS, C. (1980) The Architectural Sign, Signs, Symbols and Architecture, eds. G. Broadbent, R. Bunt, C. Jencks, John Wiley\&Sons, New York; 71-119.

JENCKS, C. (1981) The Language of Post-Modern Architecture, Academy Editions, London.

KEMP, W. (1998) The Work of Art and Its Beholder - The Methodology of the Aesthetic of Reception, The Subjects of Art History: Historical 
Objects in Contemporary Perspective, eds. M. A. Cheetham, M. A. Holly, K. Moxey, Cambridge University Press, Cambridge; 180-96.

KNAPP, S., MICHAELS, W. B. (1992) The Impossibility of Intentionless Meaning, Intention and Interpretation, ed. G. Iseminger, Temple University Press, Philadelphia; 51-65.

MARCELLO, F. (2007) The Politics of Place: citing and re-siting the Palazzo Littorio, Mussolini's New Fascist Party Headquarters in Rome, Architectural Theory Review 12(2) 146-72.

MORRIS, C. W. (1955) Signs, Language, and Behavior, George Braziller, New York.

NORBERG-SCHULZ, C. (1965) Intentions in Architecture, The MIT Press, Cambridge.

ÖNKAŞ, H. (2006) 1980 Sonrası Türkiye'de Sosyal Demokrasi: CHP örneği, unpublished Master's Thesis, Kamu Yönetimi Bölümü, Muğla Üniversitesi, Muğla.

PEIRCE, C. S. (1931-1958) Collected Papers, Harvard University Press, Cambridge; 2.247-9.

PORTER, J. I. (2011) Reception Studies: Future Prospects, A Companion to Classical Receptions, eds. L. Hardwick, C. Stray, Wiley-Blackwell, Oxford; 469-81.

PREZIOSI, D. (1979) The Semiotics of the Built Environment: An Introduction to Architectonic Analysis, Indiana University Press, London.

PROCTOR, R. (2006) The Architect's Intention: Interpreting Post-War Modernism through the Architect Interview, Journal of Design History 19(4) 295-307.

ROBINSON, J. W. (2004) Architecture of Institution \& Home: Architecture as Cultural Medium, unpublished Ph.D. Dissertation, Delft University of Technology, The Netherlands. [http://repository.tudelft.nl/view/ ir/uuid:37b0e5d5-9906-4570-97a7-6ab1c7704a3e/] Date accessed (15.11.2010).

SAUSSURE, F. D. (1986) Course in General Linguistics, Open Court, Chicago.

SIU, K. W. M. (2003) Users' Creative Responses and Designers' Roles, Design Issues 19(2) 64-73.

TEKELİ, D., SİSA, S. (1994) Anavatan Partisi Genel Merkez Binası; Ankara (1986), 1987-89, Doğan Tekeli - Sami Sisa : projeler, yapılar 1954-1994, YEM, İstanbul; 203-10.

TYSON, L. (2006) Critical Theory Today: A User-Friendly Guide, Routledge, New York.

WIMSATT, W. K., BEARDSLEY, M. C. (1954) The Intentional Fallacy, The Verbal Icon: Studies in the Meaning of Poetry, ed. W. Wimsatt, The University of Kentucky Press, Lexington; 3-18.

WISE, M. Z. (2010) A Palatial 'House of the Worker' Oscar Niemeyer's poetic monument to the Communist Party in France, The Wall Street Journal, 17 April 2010. [http://online.wsj.com/articles/SB100014240527 02303720604575169853684058116] Date accessed (10.01.2011).

YILMAZ, F. (2009) Architecture, Ideology, Representation: Party Headquarters As a New Mode in Representing Power Since the 1980's, unpublished 
Master's Thesis, Department of Architecture, Middle East Technical University, Ankara.

Alındı: 26.09.2011; Son Metin: 20.10.2014

Anahtar sözcükler: mimari, anlam, edebi eleştiri, siyasi parti genel merkez binaları, ideoloji

\section{MIMARİ YORUMLAMAYA ÇOK YÖNLÜ BİR YAKLAŞIM: SIYYASI PARTI GENEL MERKEZ BINALARINDAKİ İDEOLOJIKK ANLAMIN ARAŞTIRILMASI}

Bu yazı, edebi eleştirinin üç temel yöntemini mimari yorumlamada kullanmak üzere uyarlayarak çok yönlü bir araştırma yaklaşımı sunmaktadır. Bu yaklaşım, farklı felsefi sistemlere dayanan ve, metinsel anlamı sırayla yazar, metin (dil) ve okur odaklı ele alan maksatçı, yapısalcı ve yapısalcı sonrası dönemi kapsamaktadır. Mimari bağlamda metin anlam ilişkisi, bu yazıda özel olarak, siyasi parti genel merkez binaları - parti ideolojileri biçiminde kurgulanmış ve; önerilen yaklaşım, başkent Ankara'da dört büyük partinin genel merkez binasındaki ideolojik söylemin incelenmesinde uygulanmıştır. İlk olarak, gerçek anlamı ancak yazarın bilebileceğini savunan maksatçılık, ideolojik bağlantıları da sadece tasarımcının kendi ifadelerinde aramıştır. Böylece anlam, mimarlara tasarım kararlarını soran görüşmelerden elde edilmiştir. Yapısalcı bir okuma ise, dilbilim ve göstergebilim temelleri üzerinden binalardaki ideolojik yan anlamları belli kurallar ve şemalar üzerinden tartışmıştır. Son olarak, daha öznel, tarihsel ve estetik yorumlarla ilgilenen yapısalcılık sonrası alımlama kuramı ve okur merkezli bir eleştiri kişilerin binaları ideolojik anlamda nasıl değerlendirdiğini sorgulamıştır. Belli sayıdaki bir katılımcı grubuna yapılan anketler binaların ne şekilde algılandığını ve tanımlandığını göstermiştir. Sonuçta, anlamın üretildiği yere göre yapılan bu üç çözümlemenin her biri binalardaki ideolojik anlamla ilgili farklı bir boyutu gözler önüne sermiştir. Ortaya konan bu çok yönlü yaklaşımın, verilen alan araştırmasında olduğu gibi mimarideki birçok anlam ve yorumlama çalışmasında da, özellikle yöntemsel ve kuramsal farkındalığın açığa çıkmasında etkili olacağı düşünülmektedir.

ASLI ÇEKMIŞ; B.Arch, MSc., PhD.

Received her B.Arch, MSc. and PhD. in architectural design from İstanbul Technical University, Faculty of Architecture (2006- 2009- 2014). Currently works as a teaching assistant at İstanbul Technical University. Major research interests include interpretation in architecture with a particular focus on the theories and methods in literary criticism. cekmis@itu.edu.tr

ORHAN HACIHASANOĞLU; B.Arch, M.Arch, PhD.

Received his B.Arch from Middle East Technical University, Faculty of Architecture (1979). Earned his M.Arch and PhD. degrees in architectural design from Istanbul Technical University (1981- 1986). Currently works as a professor and the Dean at Özyeğin University. He teaches architectural design, urban design, morphology, identity, and research methods. orhan.hacihasanoglu@ozyegin.edu.tr 
